\title{
How To Motivate Knowledge Workers To Impact The Bottom Line
}

Freda Turner, (E-mail: fturner@email.uophx.edu), University of Phoenix

\begin{abstract}
Budget reductions, less volunteerism, increased needs for services, new governmental regulations, and downsizing have left non-profit organizations struggling to meet goals and objectives with fewer resources. One way non-profit organizations can increase effectiveness is to tap into their own intellectual resources and implement an employee suggestion/involvement program. The labor force has emerged from a 'hired hands' concept to one of knowledge workers. It is estimated that approximately 35\% of suggestions submitted by employees save time, money or identify strategies and/or processes for increased effectiveness ("Promote Your Employee Involvement Program", 2003). Every workforce has creativity and experience within its ranks and if leaders properly tap their employee talent pool, there is potential to increase productivity. Many organizations have downsized and re-engineered to the point that the next evolution of productivity gains will emerge from an organization's own pool of knowledge workers. This article provides examples from various organizations that have benefited from using employee suggestions, provides 15 strategies to build an effective program, and offers ideas to increase employee participation.
\end{abstract}

\section{Moving from the Hired Hands Paradigm to the Knowledge Worker}

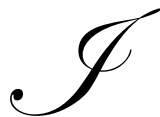

$\mathrm{n}$ the last two centuries, the social structure of the work environment has drastically changed from individuals working in the agricultural and domestic employment sectors to an environment of the knowledge worker. Agricultural and domestic employment sectors include settlers, farmers, and hired hands in factories, live-in servants, tradesmen, small artisans, and apprentices, blue/pink collar workers. Historically, such hired hands were expected to leave their ideas and opinions at the front door of the workplace. In 1988, Peter Drucker coined the term knowledge worker as an employee who can help make key decisions (Pfeifer, 2003). He proposed that the managerial challenge of the future was to learn how to engage and stimulate innovation and performance of the knowledge worker within the organization. Today, many leaders realize that employees have knowledge on how to increase productivity, improve processes, save money, and thus make the organization more competitive.

Nearly 100,000 companies nationwide have suggestion programs, per Lona Christoffers, Executive Director of the Employee Involvement Association (EIA). EIA is a non-profit professional organization that helps organizations develop organizational suggestion programs. Over the past 15 years, employee suggestion programs have gained popularity and have become more sophisticated replacing wooden suggestion boxes in the break room to operations that allow employees to go online recommending suggestions. Christoffers states she expects the programs to continue to flourish amid increasing competition and economic globalization.

\section{Background of Employee Suggestion Programs}

The workplace suggestion box is believed to have started with the Japanese in 1721 when the eighth shogun, Yoshimuni Tokugawa, posted the following note at the castle gate, "Make your idea known . . . Rewards are given for ideas that are accepted" (Lloyd, 1999). Here in the U.S., one of the early implementers of an employee involvement program was Joe Scanlon. Joe was a local union president of a financially troubled steel mill. He solicited suggestions from of the employees that saved the mill during the depression (White, 1979). The success of 
this effort led him to save other organizations in financially crisis-type situations. In 1946, the Adamson Company invited Scanlon to implement an employee involvement program in their financially healthy organization. One year later, there was a $46 \%$ increase in productive efficiency. Scanlon's basic principle was that every workforce has creativity and experience within its ranks and if properly tapped has the potential to increase productivity (White, 1979). Taking Scanlon's ideas one-step further, Assistant professor of Business Ethics at the University of Wisconsin, Madison, Denis Collins (1998) authored a book, Gainsharing and Power: Lessons from Six Scanlon Plans. He based his book on his research of six union and non-union organizations that implemented an employment suggestion/involvement program. One of the surprising findings of his study was that in virtually every case, even opponents of the employee involvement program did not wish to see employee suggestions program discontinued once implemented.

Employee involvement programs have been slow to grow. Here we are, years after the Japanese suggestion idea, and it is estimated that only a small percentage of U.S companies are fully utilizing the human capital they recruit so diligently and fewer still are encouraging employees to submit ideas as part of their daily routine. The following examples show how some organizations utilize the employee suggestion/ involvement program to increase productivity, improve effectiveness and lower operating costs.

\section{Role of Leaders in Employee Involvement Program}

Organizations need committed leaders able to maximize and utilize the existing talent to create change. An article in the June 2003 edition of INC Magazine states, "Even a strong leader will falter if he ignores the ideas from of subordinates." Establishing an employee involvement/suggestion program represents a complex organizational intervention that requires non-profit organizations to make a large number of choices about their implementation and measurement. Following are some examples of non-profit organizations that have implemented an employee suggestion/involvement program and shows the outcomes when leaders listen to their knowledge workers.

\section{Organizations that benefited from listening to employees}

Hospital saves over $\$ 10 M$. An increasing number of hospitals are using employee suggestions to identify costsaving opportunities - a source often left untapped by planners charged with finding more ways that are creative to reduce costs and increase revenues. One hospital, Lehigh Valley Hospital in Allentown, Pa., is one of the many health care organizations that instituted a program as a response to increased health care costs and decreased reimbursements. This non-profit hospital saved $\$ 10$ million - $\$ 8,100,192$ in operating costs and $\$ 1,630,378$ in capital costs across the last four years after implementing an employee suggestion program. "Year after year, we had to find ways to find money, and the hospital was always asking department heads for ideas," said Jackie Straley, program manager of the hospital's suggestion program. The hospital CEO then decided to ask employees for ideas. The four-year-old program, known as Working Wonders, now receives about 450 suggestions a year through its suggestion program, she said. The program administrator projects this non-profit hospital will save a further $\$ 1.5$ million in approved ideas this fiscal year. Creativity is finding new ways to do things better and getting those ideas from employee suggestions can help solve problems and increase effectiveness and productivity within an organization.

South Florida Water and Sewer Employee Saves $\$ 295 K$. In a typical day, an average of six truckloads of roadway construction debris was hauled to a south Florida dump. Mr. Rafael Dominguez, employee of the Water and Sewer Department, suggested using a screen to sift through the debris and separate the trash or waste from the reusable fill. This resulted in roughly $75 \%$ reduction in waste disposal fees or a saving of $\$ 295,388$ a year. It is expected that additional revenue will potentially be generated from the sale of the fill. Rafael's management team listened to his suggestion that has resulted in deceased costs and more efficient operations.

$\$ 25 K$ Savings for Volunteer Jacksonville. Judy Smith, CEO of Volunteer Jacksonville, Florida is a leader that has listened to her employees. Judy reports that employee suggestions permeate the culture in her nonprofit organization and have resulted in big cost savings on such things as back-tie receptions valued at approximately $\$ 25,000$. Thanks to the ingenuity of employee, Lesley Wolfson, and volunteers, Arlene Newman and Beverly 
Horowitz, this organization spent all of $\$ 71.00$ on the black tie reception that preceded the 2003 Celebration of Service, honoring community volunteers. These receptions typically cost about $\$ 25,000$. When Lesley joined the staff, she was appalled that the organization was not getting more of the catering for the reception provided pro bono from vendors. She took it on as a project even though it was not part of her job, and mobilized approximately eight new vendors who provided fabulous food at no charge. The result was slashing the organization's reception costs by thousands of dollars. The following year, after Lesley was promoted to Director of Fund Development, she mobilized volunteers, Arlene and Beverly, to work the project. They added many of Jacksonville's top restaurants and did not take no for an answer. They have added even more restaurants and suppliers in 2003. As a result, this $\$ 25 \mathrm{~K}$ black-tie formal reception (with the exception of a few slabs of salmon- a misunderstanding with the vendor) was completely donated. The businesses received great publicity, free tickets to the event, and Volunteer Jacksonville's eternal gratitude and continued promotion (J. Smith, personal communication, September 9, 2003). As once stated by Roger Von Oech, President of Creative Think and recognized leader in stimulating creativity, "There are precious few Einsteins among us. Most brilliance arises from ordinary people working together in extra ordinary ways."

Ohio State Government Saves $\$ 260 K$. Leaders and managers within the state of Ohio realize that front line employees often have creative ideas for improving productivity and ways to save money. Ohio leaders were quick to encourage the transformation of ideas into action through the Innovation Ohio program. Ideas that are implemented make the individual or the team eligible for a monetary reward or gift certificates. Savings for the state of Ohio in 2001 totaled $\$ 260,000$ with monetary awards and only cost the $\$ 12,999$ that was paid to the suggestors (Wilkinson, 2002). Most creative ideas come from employees who look at situations from a different perspective and it is through great leadership and management that ideas emerge until changes that positively impact productivity. Business brilliance can be as simple as listening to employees' ideas.

Miami-Dade Empowerment Trust Suggestion saves \$11,055 annually. Ms. Maria Santos observed that language translators were hired for community zoning Appeals Board meetings, but rarely used. She suggested that citizens be provided notice that language translators would be available only upon request. This reduced the cost spent on the service by $\$ 11,055$ during the first year of implementation. The management team listened to this employee.

Fire Rescue Department saves \$161,75l. Captain Gardner, an employee of the Miami-Dade Fire Rescue Department suggested creating an alternative and cost effective Basic Life Support (BLS) transport option for personnel and the public. Utilizing existing equipment and personnel on overtime pay, Gardner's BLS Squad has generated an additional $\$ 161 \mathrm{~K}$ in revenue for the county and improved the standard of service in many communities. Fire Rescue units no longer wait for 30 to 40 minutes for ambulances thanks to the implementation of this employee idea service.

Facility Management saves $\$ 590 \mathrm{~K}$. A team of 14 employees from the facilities management department of a hospital was seeking contractors to construct new nurse stations as part of an expansion project; they were quick to suggest that the construction work be done in-house to cut costs such as labor and materials. And they did: they saved the hospital $\$ 590,000$. The team of employees - who ranged from the department secretary to project managers - drew up a proposal that involved hiring three carpenters and temporarily converting an on-site helicopter hanger into a workshop for the construction. For their idea, the team received a $\$ 22,500$ check that they divided equally among the employees.

\section{Strategies to Build or Revitalize an Employee Suggestion/Involvement Program}

The following tips are best practices in establishing or revitalizing an employee suggestion/involvement program:

\section{Top Management Support must be VISIBLE and Motivate}

Senior Management must have a champion member for the program within the executive team that discusses the program status at meetings. Developing an effective employee suggestion program requires 
enticement activities that can demonstrate management's desire for inclusion of all employees. For example, if the CEO cannot kick it off personally, he/she should record a personal video message or some form of communication to pass his/her commitment to his/her knowledge workers. A couple years ago, the prior CEO of Southwest Airlines, Herb Kelleher, sent a personal letter to employees at their home encouraging their participation to drive down operating cost (Nelson, 2002). His letter reminded each worker that the cost of aviation fuel had increased tremendously, and in order to remain competitive within the airline industry, he was asking each employee to submit suggestions on ways the organization might save at least $\$ 5.00$ in the area where they worked. Within six weeks, Southwest Airlines had millions of dollars worth of money saving recommendations. Think about it. Most everyone can think of a way to save $\$ 5.00$ in their work environment. Another method of showing knowledge workers that top management is interested and supportive in their ideas is to have surprise reward presentations to award department employees who submit accepted suggestions. Ensure all the department heads attend the check presentations. Show pictures at new-hire orientation of senior management giving rewards to staff members that submit ideas. Successful employee suggestion programs have VISIBLE top-management support! According to a March 2001, article reported in USA Today, a survey developed by OfficeTeam found, "Only 38\% of working men and women feel their managers are very willing to listen to new ideas and suggestions for improvement." Top management should let everyone-- on every level-- know that top management is supportive of the employee suggestion/involvement concept and that employee participation is instrumental to organizational success. In some organizations, the CEO will review all non-adopted ideas. Jack Stack, author of Great Game of Business, is noted for saying, "If no body pays attention, employees stop caring."

\section{Identify a Program Administrator}

The number one reason employee suggestion/involvement programs fail or is ineffective is because there is no full time administrator. Designate an individual to administer the program -- not to accept or reject suggestions but to act as a liaison between employees and management and to track suggestions and savings. The program administrator should tie the suggestion program goals to management's objectives, activities, values, and mission. Program Manager should support the employee as the idea moves through the system with such items like cost benefit analysis. In addition, the administrator should develop a process that includes responding promptly to each suggestion. For the employee involvement program to work, there needs to be someone senior responsible for the program. A poorly run system will demoralize employees. The program should acknowledge employee contributions via rewards, debriefings, ongoing feedback. This administrator's performance should be evaluated on number of suggestions that come in, department and employee participation rates, implementation rate, and savings/benefits rate. One word of caution is upon successful launch of a new program, one might expect the volume of employee suggestions to increase rapidly in the period immediately following the introduction, and then it might start declining. There are two main reasons to expect this curvilinear pattern in the volume of total suggestions over time. First, the attention paid to employees during the early part of the employee involvement program may lead employees to submit an inordinately high number of suggestions. This is known as the Hawthorne Effect, a study based on the findings from the classic studies at the Hawthorne Works of the Western Electric Company in the 1920s and '30s. This explanation is consistent with Griffin's (1988) finding that that there was a cycle for quality circle effectiveness, with peak effectiveness occurring in the third year and then declining. This same life-cycle observation has been made by a number of researchers regarding the effectiveness of employee participation and incentive programs (Cooke, 1989; Gray, 1971; McKersie, 1963). Secondly, Hammer (1988) noted, a key assumption of the participation view of employee suggestions is that employees have pent-up ideas that are released in the form of suggestions once the program is introduced. If this assumption is correct, it follows once pent-up ideas have been submitted, a decline in the number of suggestions over time may occur. The assigned program manager should be visible, proactive in stimulating new and on-going interest in the program, and work with new hires to minimize this decline in ideas.

\section{Publicize Program Internally and Externally}

Open the suggestion program to every employee, vendor/customer internally and externally. Many organizations are now computerizing their programs; however, if you do this, ensure all vendors/employees/customers have access to the computer suggestion program or web site. If not, a traditional box 
should be installed and MONITORED. If the suggestion program is too complex, individuals will not participate. Keep the suggestion process simple and the need for immediate feedback is emphasized. Expose all accepted ideas on a bulletin board in the cafeteria or an area where employees can read to stimulate thought, discussion, and interest in the program. Establish a need for improvement within the organization. CEO Jack Stack, a brilliant business executive of the century, provides a good example on the value of soliciting ideas of others. In the early 1980s, Jack became CEO of the near-bankrupt organization of Springfield Remanufacturing in Springfield, Missouri. He was new at leading and managing a company. He created a new management style that has been coined, open book management. In essence, he communicated to everyone about profitability status of the organization and invited employees to have a voice in the organizational success. Springfield Remanufacturing did not bankrupt and in fact has become incredibly profitable due to the employee suggestions. This business model is taught in many business programs. He taught even employees with a sixth grade education about profits and costs and each individual knew how much toilet paper was costing the organization. Of prime importance is communication within an organization. Ensure employees realize the competitive reasons to submit ideas, to improve processes, eliminate waste, or help position the organization to be more competitive in the global market place. Some organizations include this employment involvement message in their recruiting process and new hire orientation. Some employee suggestion administrators invite employees whose suggestions have been implemented to share their experience to new hires at orientation how their suggestion has influenced the organization. This can be accomplished either by having the suggestor deliver the message in person or via video Ensure suggestion program articles appear in the organization's newsletter along with photographs to keep the message visible that employee ideas are valued. If the organization has an Intranet or Internet site, allow electronic idea submissions and ensure the employee receives a copy of the idea via email as confirmation.

\section{Beware of the Threatened Manager Syndrome}

Historically, there have been managers who fear subordinates looking too good, and employee ideas have been suppressed and even stolen. Keep employee involvement programs on the front burner to reap competitive opportunities for the organization. Encourage and reward managers who actively solicit employee involvements. Managers may feel threatened when subordinates receive recognition. Eliminate fear and reward managers who create a learning environment of better ideas/suggestions. One organization that has profited from employee involvement is Miller Electric. In the article, "Tough times are when employee involvement counts the most." John Torinus writes, "The 1,300 employees have already launched 900 improvement projects this year. The goal is 2,000" (Torinus, 2003, p. 2). In discussing Miller's Chief Executive Officer Mike Weller's philosophy on employee involvement, Torinus goes on to write, "He pushes hard to get employees to take on more responsibility and risk. Each employee has individual goals and objectives for the year and these are part their part of the merit system" (Torinus, 2003, p. 2.) Sales and profit have grown substantially at Miller Electric. CEO, Mike Weller, attributes this incremental profit substantially to Miller's employee involvement program at all levels.

\section{Develop Department Goals}

Assign departmental suggestion program goals and departments that attain the goals can receive a plaque, pizza parties, etc. This encourages the managers to stimulate employees to submit ideas that are aligned with organizational goals such as decreased waste, better customer service, lower accident rates, and higher employee morale.

\section{Create Themes and High Powered Promotions}

Successful suggestion promotions begin with a business plan. Launch promotions that rallies around a theme, product, service, or a calendar event that is tied to organizational goals and objectives. For example, IdeaAAs in Action (American Airline Suggestion Program) launched using confetti, balloons, a party blower and a small popper containing a grain of gun power mailed to each employee. The idea was to promote a fun program while soliciting ideas that could influence the bottom line in this highly competitive industry. Thousands of employees responded, generating \$50 million in savings over a 14-week period for American Airlines(Promote Your Employee Involvement Program, 2003). Incorporate a variety of communication vehicles for the program that might include 
desktop produced flyers, videos, bulletin boards, a wall of honor of accepted suggestions and photographs, newsletters or electronic mail. The more employees that know about the program, the more ideas will come in.

\section{Create a Branding for the Suggestion Program}

Create a memorable name and logo that targets the purpose of your program. Some examples used by other organizations includes: American Airlines incorporates the corporate AA logo into IdeaAAs in Action for their suggestion program. Martin Marietta Aero \& Naval Systems program is called Working ideas Together (WIT) and Allentown, Pa-based Lehigh Valley Hospital and Health Networks created a slogan, "Together, We can Work Wonders" and they have shortened their program name to Working Wonders.

\section{Rotate Suggestion Advisory Steering Committee Members}

Set up a cross-functional advisory committee that represents various departments to evaluate the merit of submitted suggestions. These individuals can also deliver messages about the program success at new employee orientations. Provide training to the evaluators of submitted suggestions before the program is rolled out. Credibility is lost if initial efforts of those in charge are tentative. Rotate membership annually but stagger it, so all new members do not show up at once. Having new members presents new energy and ideas. Retired members are still great marketers for the program and should be given an honorary title of 'Suggestion Mentors.' Some organizations have the advisory/steering committee help guide the process and settle any disputes by having the department where the idea will have the greatest impact help evaluate the merit of the suggestion.

\section{Give Rewards That Matter at all Levels of the Organization}

The second reason a number of suggestion programs do not work is failure to provide awards or absence of recognition for submitted suggestions. As Tom Peters is noted for saying, "Celebrate what you want to see more of." Most all organizations reward employees with $10-20 \%$ of the first year's savings that a suggestion reaps. However, government and non-profits often provide time off, tickets to sporting events/cultural events, or points redeemable from a catalog of gift items. Additionally, employees still value recognition and having lunch with a senior member of the leadership team. This also provides a good marketing opportunity as the employee will tell others of their experience further marketing the employee involvement program. Many organizations ensure the corporate newsletters include information regarding accepted suggestions and have an 'honor wall' or 'wall of fame' that acknowledges employee contributions, has photographs, and keeps the message exposed to visitors and employees. Many organizations also have a certificate sent to the department administrator or department head of the employee thanking them for their support of the contribution. It takes a whole village...

\section{Provide Timely Feedback}

Employees need to know that their suggestions are taken seriously and that they can have an impact on the work environment. By quickly reviewing, providing feedback and implementing suggestions that have merit, management sends a strong positive message. Timely feedback is VERY important.

\section{Keep the Submission Process Simple}

Suggestions should include a business case for money or time saved if the suggestion is implemented.. Keep the process simple as possible for the employee but the suggestion should include its value/ benefit, who it will impact or affect, and implementation and cost estimation strategies. Some organizations have the department estimate the cost savings vice the employee. Some organizations have implemented software into the corporate email system that helps employees build a business case. 


\section{Establish a Program Mentor Program}

Another bonding strategy used by some organizations is to have prior suggestors mentor prospective suggestors. American Airlines initiated a mentor system to increase employee participation in its "IdeAAs in Action" program. Mentors receive one day of training and then work with others to encourage cost-savings ideas, how to submit the suggestion and the process the suggestion will go through until implementation. Don't forget to acknowledge contributions of mentors - they help keep the program alive.

\section{Allow an Anonymity Option}

Some program managers provide a confidentiality option in unionized environments. Here is a real example that occurred in an unionized, automobile environment. A suggestion was submitted that resulted in a staffing change in an area where productivity showed employees only worked two hours per shift. The suggestor made upper management aware that over-staffing was definitely a problem and redeploying jobs to needed areas would improve productivity at the plant. There were no lost jobs - just redistribution of the knowledge workers. The idea was investigated and the under- utilized employees were transferred to another area of the plant. Unfortunately, the transferred employees did not see the value aspect of the suggestion. The suggestor started receiving threatens of harm and had to be medically ordered to stay out of work for the next six weeks until things cooled down. Some unions disapprove of employee involvement programs as some suggestions may result in lost jobs. A partnership should be investigated here. Some organizations have implemented the following practice: Upon receipt of a suggestion, the name of the suggestor and any other marks of information that might reveal the suggestor's name are removed, and thereafter, the suggestion shall be known only by an identification number.

\section{Review Suggestion Programs Annually}

Every process can be improved so reviewing the suggestion program annually to monitor its effectiveness is well worth the time. As with any other program, areas needing improvement should be identified during annual program reviews. The administrators of the program can post "FAQ" lists to help employees better understand the process. This annual review should be a line item in the corporate culture survey.

\section{Join Employee Involvement Association (EIA)}

The Employee Involvement Association is a 61-year old, non-profit professional organization where members collaborate to improve organizational effectiveness through employee suggestions and can benchmark programs with other suggestion program Administrator/Managers. The organization offers training and certification classes for employee suggestion administrators and evaluators. Their web site is www.eianet.org and members belonging to this professional organization have access to white papers, videos, publications, legal guidelines, and statistics relating to benefits of an employee suggestion program. More information on this non-profit organization is available: Employee Involvement Association, 7925 E Lakeview Avenue, Mesa, AZ 85208. Telephone: 480358-1791 or fax 480-358-1866.

\section{Ways to Increase Participation of Suggestion Programs}

Other organizations have increased participation in suggestion programs using the following:

\section{Run Promotions}

Promotions are the lifeblood of any employee involvement program. Keeping employees interested and involved takes time and effort and not always a lot of money. Give your employee suggestion promotion plenty of publicity and publish the results gained for the organization from employee suggestions. Purchase gift baskets, weekend get-a-ways, and move the display items from department to department and/or to the cafeteria to stimulate employees to submit ideas. Give away small gifts should as T-shirts, writing pens, coffee mugs to market the program and increase participation. 


\section{Publish Employee's Ideas in Organizational Newsletters}

Communicating the suggestion program is a good method to keep the program in the forefront of employees' minds. Include material from the top suggestions that have been implemented, team contributions, procedures on how to submit a suggestion. Send letters to new hires encouraging their ideas and explain how the employee suggestion/involvement program works and benefits the organization.

\section{Reduce Evaluation Time}

Nothing demoralizes employees more than lack of feedback or a slow process in making an acceptance/denial decision when a suggestion has been submitted. Send each suggestor an email or letter keeping him/her informed of the status within 48 hours.

\section{Involve Senior Management}

When possible, have senior executive publicly present checks/rewards/ letters of appreciation to employees whose suggestions are adopted.

\section{All Organizations Could Use Some Zapp}

A top selling book in the late 1990s, Zapp The Lightning of Empowerment, by William C. Byham illustrates the importance of employee involvement that goes beyond profitability. The author describes employee involvement and the book has been written in a very entertaining story format. Joe Mode, a character in the book, keeps a notebook that documents organizational behavior concepts. Joe Mode's notebook states, "When you have been Zapped, you feel like, "your job belongs to you, you are responsible, your job counts for something, you know where you stand, you have some say in how things are done, your job is a part of who you are, and you have some control over your work" (Byham, 1998, p. 56.) Without a doubt, Joe Mode makes a very good case for employee involvement that goes beyond just the profitability angle. All organizations could use a little more Zapp today from each employee.

\section{References}

1. Byaham, W.C. (1998). Zapp! The Lightning of Empowerment. New York: The Ballantine Publishing Group.

2. Cooke, W. N. (1992). Product quality improvement through employee participation: The effects of unionization and joint union-management administration. Industrial and Labor Relations Review, 46: 119-134.

3. Foreman, D. Employee ideas enhance, improve, save millions. Business Journal. 17, 47, 4.

4. Gray, R. B. (1971). The Scanlon plan: A case study. British Journal of Industrial Relations, 9: 291-313.

5. Griffin, R. W. (1988). Consequences of quality circles in an industrial setting: A longitudinal assessment. Academy of Management Journal, 31: 338-358.

6. Hammer, T. H. 1988. New developments in profit sharing, gainsharing, and employee ownership. In J. P. Campbell \& R. J. Campbell (Eds.), Productivity in organizations: New perspectives from industrial and organizational psychology: 328-368. San Francisco: Jossey-Bass.Lloyd, G. C. (1999, August). Stuff the suggestion box. Total Quality Management, 10, 869-875.

7. McKersie, R. B. 1963. Wage payment methods of the future. British Journal of Industrial Relations, 1: 191-212.

8. Nelson, B., Ph.D. (2002). Tap into employees to get good ideas. Retrieved from http://itmanagementnews.com/2002/0506.html on July 22, 2002.

9. Pfeifer, S. (2003, June 15). U.S. Suffers from "Performance Crisis' among Workers. Knight Ridder Tribune Business News, p. 1.

10. Promote Your Employee Involvement Program. (2003). About the Employee Involvement Association (EIA).

11. Torinus, J. (2003, June 15). Tough Times are when employee involvement counts most. Milwaukee Journal Sentinel, p. 2.

12. White, J. K. (1979). The Scanlan Plan: Causes and Correlates of Success, Academy of Management Journal, 22, 2, 292-312.

13. Wilkinson, R. A. (2002, June). The bureau of staff enrichment: Employees are our most valuable resource. Corrections Today; 64, 3, 84-87. 